\title{
Transport poverty and its adverse social consequences
}

Karen Lucas PhD, MA (Res), BSc (Hons)

Professor of Transport \& Social Analysis, Institute for Transport Studies, Faculty of Environment, University of Leeds, Leeds, UK (corresponding author: K.Lucas@leeds.ac.uk)

Giulio Mattioli PhD, MSc (Hons), BSc (Hons)

Research Fellow, Institute for Transport Studies, Faculty of Environment, University of Leeds, Leeds, UK
Ersilia Verlinghieri MSC (Hons), BSc (Hons), BMus

PhD candidate, Institute for Transport Studies, Faculty of Environment, University of Leeds, Leeds, UK

Alvaro Guzman MSc, BSC

PhD candidate, Institute for Transport Studies, Faculty of Environment, University of Leeds, Leeds, UK

Transport poverty is an issue that has never fully captured the interests of the transport engineering profession in either the 'global north' or 'global south' and yet it is a problem that adversely affects the daily lives of millions of people across the globe. What precisely constitutes transport poverty is not adequately articulated within academic, policy or infrastructure design literature. This paper aims to demonstrate how the different ways that academic studies and policy programmes have defined and recorded the problem of transport poverty is directly related to the ways in which it has been subsequently addressed in practice. The overall impression is one of inadequacy, fragmentation, inconsistency and tokenistic treatment of an issue that potentially affects anywhere between 10 to $\mathbf{9 0 \%}$ of all households, depending on which definition is used and which country is being considered. This suggests that it is a far greater problem than the transport profession has previously been prepared to recognise and one that requires its urgent attention given the continuing trends for mass migration, urbanisation and wealth concentration within and between the 'global north' and 'global south'.

\section{Introduction}

Various texts implicitly or explicitly refer to the problem of transport poverty, including those written by academics such as Lucas (2004; p. 291) and Litman (2015; p. 2), official policymaking bodies such as the UK's Social Exclusion Unit (SEU, 2003) and UK Department for Transport (DfT, 2006) and lobby organisations such as the UK's Royal Automobile Club (RAC Foundation, 2012) and the Campaign for Better Transport (CBT, 2012). However, does it really exist as a stand-alone phenomenon; that is, is it something that is somehow fundamentally different to being simply poor per se? If it does exist, how easy is it to understand who might be affected and to convey its negative social consequences to policymakers? Furthermore, and perhaps more importantly, what should be done about it?

For example, is transport poverty a real problem for individuals, or is it a systemic problem that needs to be addressed more strategically at the community level, city-wide or across whole regions? Are different types of solutions needed, depending on who is affected and where they are physically located or will adjustment of some of the blanket policy measures that are currently used within transport policy, such as concessionary fares, operating subsidies for socially necessary public transport services and supplementary community transport services work just as well to resolve the problem? Finally, is this ultimately even a transport delivery problem at all or one of urban and rural planning or for social welfare services to resolve?
Although is not possible to address all of these issues within this paper, the authors attempt to provide an overview of the various ways in which transport poverty has been previously conceptualised within the available literature, as well as to offer for discussion some newly devised definitions. These different definitions are used to discuss how transport poverty might be measured, illustrating how different methodological approaches might be required, depending on the nature of the problem. A brief analysis is then presented of the publically available datasets that can be used to explore transport poverty and identify some important gaps in these datasets that need to be addressed in order to improve future analysis in this respect. Finally, a flavour is given of some of the policy approaches that have been brought into play to address different aspects of the problem of transport poverty.

The paper is intended as a state-of-the-art review and think piece about how transport poverty has been conceptualised within the current literature, rather than an empirical study report. The primary focus is on the experience of countries of the 'global north' and in particular the UK, although examples are also taken from elsewhere. This evidence-base is used to consider the ways in which transport poverty might need to be explored differently within the 'global south' given the more extreme depth, breadth and intensity of the problem within the developing world.

One of the most important issues that transport professionals need to understand and communicate better are the severe 
social consequences of transport poverty, not only for the people who are directly affected by it, but also for society as a whole. It is already evident that the transport conditions and mobility behaviours of lower-income population groups have very specific patterns that are highly differentiated from their higher-income counterparts in almost every country in the world. Specific recognition of these differences is extremely important for the planning and delivery of economically, environmentally and socially sustainable transport systems.

First of all, the poorest groups in any given country tend to be less mobile. They most often suffer from a lack of both private and public transport services in terms of the number of options and the quality of services that are available to them (Barter, 1999; Titheridge et al., 2014). As such, they are forced to rely on options such as walking and cycling, often over long distances and in unsafe conditions. They are, therefore, also more exposed to road-related casualties and deaths and to traffic-related pollutants (both in the living/working areas and in their mobility patterns), which also has knock-on negative consequences for their health and well-being (CBT, 2012; Titheridge et al., 2014).

At the same time, in urban areas poor people are most often located in peripheral locations at the edges of cities with a low amenity value, where there are few local employment opportunities and an absence of local services and basic facilities. This conflates with their lack of access to transport options to produce a 'poverty trap', which limits their wider access to jobs, education and health facilities, social networks and more generally their 'right to the city' (Harvey, 2003).

From a land-use planning perspective, especially in developing contexts, there is a disconnection between the mobility needs of low-income, non-car-owning citizens to move and act freely within compact and walkable cities and the development trend for segregated, gated, car-friendly and gentrified settings, which correspond with the lifestyle preferences of middle- and higher-class populations (Barter, 1999; Soja, 2010).

A number of academic studies have suggested that the poorest sectors of society also do not equally benefit from new or improved transport infrastructures and services (e.g. Booth et al., 2000; Gachassin et al., 2010; Hettige, 2006; Khandker and Koolwal, 2011; $\mathrm{Mu}$ and van de Walle, 2011). This may either be because they do not have access to motorised transport or because they cannot afford transit services. The poorest population groups may become even further marginalised and impoverished by the externalities of these major infrastructures through community severance and increased road casualties and deaths, as well as by the knock-on land use effects of these investments, which may serve to dislocate them further from mainstream economic activities (Starkey and Hine, 2014).

\section{Defining transport poverty}

What precisely constitutes transport poverty has never been fully articulated within either the academic or policy literatures. This is unlike, for example, the concept of fuel poverty, which in many countries now has its own relatively wellestablished set of definitions and evaluation metrics. This may in part be attributable to the more nebulous nature of mobility as a 'merit good', as well as to a less obvious causal chain between a lack of transport and any knock-on negative social consequences.

It is extremely difficult to construct a concise definition for transport poverty based on unmet household needs. First, transport poverty resides with individuals rather than the whole household (i.e. one member of a household may experience it, whereas another member of the same household does not) and is particularly polarised around gender differences (Booth et al., 2000; Robinson and Thagesen, 2004). Second, mobility is largely associated with the secondary benefit of providing accessibility to goods, services and activities. These activities are all highly socially, temporally and geographically context-specific, making it more difficult to construct a single definitive indicator of transport poverty. It is, therefore, unclear whether transport poverty relates to a deficiency in transport supply, and/or to some minimum level of mobility, and/or to a level of accessibility to goods, services and daily activities.

Furthermore, different terminologies have been used interchangeably to describe transport poverty within the various literatures. Terms such as 'transport/mobility poverty' (e.g. Ahrend et al., 2014; Martens, 2013; Velaga et al., 2012), 'accessibility poverty' (e.g. Martens and Bastiaanssen, 2014; Scheiner, 2008), 'transport-related social exclusion' (Hine, 2009) and 'transport disadvantage' (Currie et al., 2009) are used with often very different, although also overlapping definitions. This is unhelpful and, as Lucas and Markovich note: 'there is a need to establish a lexicon of definitions to ensure a greater degree of clarity and consistency within and between the academic and policy literature' (Lucas and Markovich, 2011: p. 233).

This paper attempts to establish such a lexicon (see Table 1) by putting forward definitions for five distinct, albeit interrelated (see Figure 1), notions. (It is noted that these notions and their relationships can be conceptualised in many different ways see e.g. Titheridge et al. (2014: p.4).) It proposes a distinction between

- transport poverty itself, which is explained as an overarching combination of the subset of

- transport affordability (Litman, 2015) - that is, inability to meet the cost of transport

mobility poverty - that is, the lack of (usually motorised) transport

accessibility poverty - that is, the difficulty of reaching certain key activities such as employment, education, 
Transport poverty: a broad, overarching notion, which identifies a research/policy field and encompasses the following sub-concepts

\begin{tabular}{ll}
\hline Notion & Definition \\
\hline Mobility poverty & $\begin{array}{r}\text { A systemic lack of (usually motorised) transport that generates } \\
\text { difficulties in moving, often (but not always) connected to a lack } \\
\text { of services or infrastructures } \\
\text { The difficulty of reaching certain key activities - such as } \\
\text { employment, education, healthcare services, shops and so on - at } \\
\text { reasonable time, ease and cost } \\
\text { Thessibility poverty lack of individual/household resources to afford transportation } \\
\text { options, typically with reference to the car (in developed countries) } \\
\text { and/or public transport }\end{array}$ \\
$\begin{array}{c}\text { The outcomes of disproportionate exposures to the negative effects } \\
\text { externalities }\end{array}$ & $\begin{array}{l}\text { of the transport system, such as road traffic casualties and chronic } \\
\text { diseases and deaths from traffic related pollution. Often } \\
\text { considered within the US literature from an environmental justice } \\
\text { perspective }\end{array}$
\end{tabular}

References

Moore et al. (2013)

DfT (2014a), SEU (2003)

Carruthers et al. (2005), Litman

(2015), Serebrisky et al. (2009)

Barter (1999), Booth et al. (2000)

Table 1. A lexicon of definitions for transport poverty

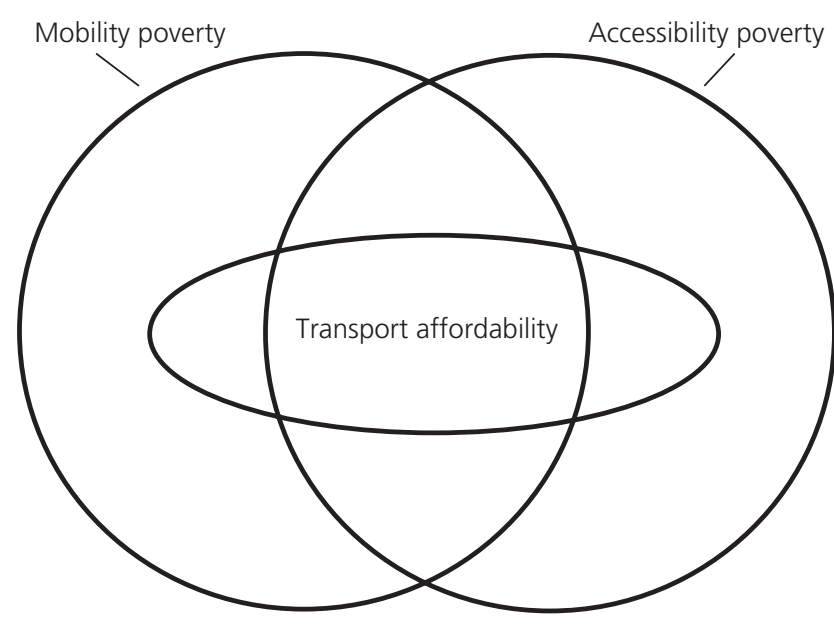

Figure 1. Transport poverty and related sub-concepts (authors' own elaboration)

healthcare services, shops and so on (Abley, 2010; Harris, 2001)

- exposure to transport externalities - in its broadest definition, transport poverty can also been seen to include the disproportionate negative exposures to the transport system itself (Barter, 1999; Booth et al., 2000; UN-Habitat, 2013).

\subsection{Transport affordability}

This first and rather narrow definition of transport poverty, with its identification of car ownership as a basic household need, is mostly only relevant within the context of the hyper-mobility of developed countries in the 'global north'. Gleeson and Randolph (2002: p. 102) consider that: 'transport poverty occurs when a household is forced to consume more travel costs than it can reasonably afford, especially costs relating to motor car ownership and usage'. Within this definition, Currie and Delbosc (2013) are able to explore a connection between transport poverty and forced car ownership, where low-income households have to spend a high share of their income on running cars owing to lack of public transport alternatives (Denmark, 1998; Hine, 2009; Rodrigue et al., 2006) and also suffer the highest public transport fares.

It is clear, however, that transport-poor populations in the 'global south' are currently largely exempt from this discourse, where even being able to afford bus fares to access formal transit services is often out of the reach of most low-income households. In other circumstances, affordable transport options that are available might lead to other stresses in terms of the journey time required, unsafe and uncomfortable travelling conditions, and so on. However, as the urban populations of many developing countries become more and more dependent on the use of private motorised vehicles, it is likely that the people who cannot afford even these modes of transport will become similarly marginalised (as their low-income counterparts in the developed world) from participating in everyday life chance activities (Booth et al., 2000).

In developed countries, as Litman (2015) highlights, there is indeed a narrow link between transport affordability and social exclusion, as unaffordable transport can exclude people from accessing basic activities such as education or shopping. 
Moreover, it can lead to the sacrifice of essential expenditures such as food or medicines. The goal of ensuring affordable and inclusive public transport services should be traded off against that of ensuring sufficient revenue for good quality services. This can only be achieved through some form of financial subsidy, most usually delivered through the State (Gwilliam, 2002).

\subsection{Mobility poverty}

While the concept of transport affordability refers to the lack of individual resources to afford transportation options, mobility poverty refers more to a systemic lack of transportation and mobility options. In this context, there is a proved correlation between low income and mobility poverty, whereby mobility problems are the result of poverty situations and at the same time compound them. Mobility poverty might be connected to a lack of transit services or infrastructures. However, major infrastructure investment does not necessarily address the needs of the most poor (as discussed in Section 3.3), as transport investment backed up by the economic growth agenda 'tends to benefit the 'non-poor' most' (Starkey and Hine, 2014: p. 7).

\subsection{Accessibility poverty}

Accessibility poverty extends the concept of mobility poverty to consider in addition whether people can reach their basic daily activities within a reasonable time, ease and cost (Preston and Rajé, 2007; SEU, 2003). In the 'global north', accessibility poverty has helped to identify the social groups that lack the basic resources to be able to access key activities that support their life chances, such as employment, education and health visits; it also takes account quality of life issues (Olvera et al., 2008; Pereira and Schwanen, 2013). If transport is understood as a means to satisfy other needs and rights (Cebollada, 2006), accessibility poverty acts to reproduce the general conditions of poverty and it is clearly connected with social exclusion (see Lucas (2012) for a full discussion of the literature concerning transport-related social exclusion).

To apply the accessibility poverty concept within countries in the 'global south' would pose new conceptual and operationalisation issues. The accessibility approach would mean that transport planners should consider transport provision in relation to other areas of social policy delivery such as housing and access to activities - for example, employment, marketplaces, healthcare and education (Pinto de Freitas, 2005; Porter, 2014). There is also more of a compelling need to consider the service quality and safety dimensions of people's travel experiences, whether by public transport or nonmotorised modes, as well as the temporal dimension in terms of long travel distances, both to and from transit services and also while walking. This again has similarities with debates on domestic energy, where developing a global perspective on energy deprivation requires going beyond the narrow understanding of 'fuel poverty' that has dominance within the UK policy context (Bouzarovski and Petrova, 2015).

\subsection{Disproportionate exposure to transport externalities}

There are two environmental-related aspects of transport poverty: (a) the disproportionate direct exposure of certain population groups to traffic-related environmental externalities, such as air and noise pollution, as well as traffic-related pedestrian casualties and deaths; and $(b)$ the various dis-amenities of transport infrastructure projects on the lives and livelihoods of the local communities who are living alongside them, as well as the disbanding and dislocation of communities as a result of building these projects. The CBT (2012) and the UN-Habitat report (Barter, 1999) record that those on low incomes (particularly in the 'global south') are far less likely to own a car, but face many of the problems that society's dependency on the car causes: on a global scale, low-income communities are paying 'a disproportionate share of external costs' (Barter, 1999) by being much more exposed to these problems.

\subsection{A new definition of transport poverty}

Based on this lexicon of individual definitions, the authors have devised the following working definition of transport poverty for the purposes of further exploration, critique and policy formulation within subsequent sections of the paper: An individual is transport poor if, in order to satisfy their daily basic activity needs, at least one of the following conditions apply.

- There is no transport option available that is suited to the individual's physical condition and capabilities.

- The existing transport options do not reach destinations where the individual can fulfil his/her daily activity needs, in order to maintain a reasonable quality of life.

- The necessary weekly amount spent on transport leaves the household with a residual income below the official poverty line.

- The individual needs to spend an excessive amount of time travelling, leading to time poverty or social isolation.

- The prevailing travel conditions are dangerous, unsafe or unhealthy for the individual.

Each of these phenomena can of course also be a subset of the other (Figure 1) and may not be distinguishable from the point of view of the person affected, but they do have different implications in terms of appropriate policy response to address transport poverty, as discussed later in the paper.

\section{Measuring transport poverty}

Having identified what transport poverty looks like, it is then possible to think about how to measure its incidence within any given population group or within a geographical area. The next two sections aim to demonstrate that if only partial aspects of the transport poverty problem are recorded (i.e. only 
affordability, mobility, accessibility or externalities), then it is likely that this will be a key determinant in understanding exactly who is affected and the shape of the policy solutions brought forward.

This section discusses some of the indicators and metrics that have been identified within the literature as useful for measuring the different dimensions of transport poverty (summarised in Table 2). These suggested measures are intended to be indicative only and any benchmarks will be highly contextspecific and dependent on the prevailing transport and landuse conditions of the country or city that is being appraised. Section 4 presents some of the data sources on transport poverty that are currently available in the UK. Figures 2 and 3 exemplify which indicators can be drawn from these sources, reporting values for the UK in 2012.

\subsection{Measures of affordability}

Various measures of transport affordability have been proposed in the literature. A first group of measures refers to actual transport expenditure as a share of income. In the UK, the RAC Foundation proposed to define households spending more than $10 \%$ of their income on transport as 'transport poor' (2012), mimicking the pre-2012 official definition of fuel poverty. Similar measures are adopted in developing-country studies, often comparing the (public) transport expenditure of poor households to a benchmark of average users (for a review see Serebrisky et al. (2009)). These measures have two key limitations. The first focuses on actual expenditure, rather than on normatively defined need (as is the case for fuel poverty), and means neglecting issues of 'suppressed travel demand'. Households may need to spend a high proportion of their income on transport but avoid doing so, limiting their travel in order to ensure the satisfaction of competing needs. The second limitation is transport expenditure, which (unlike domestic energy) is non-regressive in most developed countries; that is, richer households spend on average a higher proportion of income on transport (this is often not the case in developing contexts, where, owing to massive income disparities, the proportion of income that low-income families may spend on transport is $20 \%$, whereas wealthy families usually spend only around $5 \%$ ).

To avoid the problem of suppressed travel costs, Carruthers et al. (2005) defined a measure of public transport affordability as the percentage of income needed to undertake sixty $10 \mathrm{~km}$ one-way trips per month. The study constructed an affordability index for 27 cities distributed across the developing world, and included some of the developed world. In studies focusing on developing contexts, measures often refer to public transport expenditure only (e.g. Serebrisky et al., 2009), reflecting the assumption that car ownership and use are a matter of luxury rather than necessity. In developed countries, private transport costs are typically included, reflecting the assumption that car ownership and use can be a necessity in car-dependent societies. Linked to this are measures of the vulnerability of households to fuel price spikes (Dodson and Sipe, 2007), which can be construed as measures of 'potential' transport affordability. These measures typically consider areas of low income and high car dependence as particularly at risk. A similar approach is adopted by Sustrans for their maps of transport poverty in England (Sustrans, 2012).

Another limitation of measures based on transport expenditure only is that they do not take into account housing costs. Households might offset higher transport costs with lower housing costs (and vice-versa), and often trade off the two when making residential location choices. Therefore, indices taking into account combined housing and transport costs have been applied in both developed (Litman, 2015) and developing countries (Isalou et al., 2014).

What is clearly important here is to ensure that transport affordability is considered not as an absolute measure, but relationally $(a)$ in the light of other measures of poverty and $(b)$ in relation to affordability in other crucial areas (such as housing). It is also important that transport affordability is calculated against some average measure of spend for similar household types or geographical locations.

\subsection{Measures of mobility}

Measurement of the revealed mobility of different social groups is probably the most common way in which transport researchers have traditionally explored issues of transport poverty. In their review of the literature, Moore et al. (2013) describe the various methodologies to measure mobility among socially disadvantaged groups. Most commonly, such studies point to differences in trip-making patterns of different social groups using stratifications such as gender, age, income, employment status, and so on. Three variables for measuring this are usually used

(a) trip generation measures the number of trips a person or a household makes during a period of time (e.g. Roorda et al., 2010; Schmöcker et al., 2005)

(b) trip distance can be used to measure mobility as well to offer as an implicit measure of accessibility (e.g. Maoh and Tang, 2012; Morency et al., 2011; Van den Berg et al., 2011)

(c) trip duration has been modelled using transport network approaches because time of travelling is most often dependent on the network characteristics, the mode and levels of use (e.g. McQuaid and Chen, 2012).

\subsection{Accessibility-based measures}

Research to develop accessibility measures for transport inclusion often already includes consideration of both the affordability and mobility aspects of transport poverty (Carruthers et al., 2005). For example, in the UK, accessibility planning is based on assessing whether 'people are physically and financially able 


\begin{tabular}{|c|c|c|c|}
\hline Indicator & Metrics & Benchmark & Source \\
\hline \multicolumn{4}{|l|}{ Affordability } \\
\hline $\begin{array}{l}\text { Transport affordability } \\
\text { Mobility }\end{array}$ & Income, quantity of travel, single trip fare & Average and bottom quintile per capita incomes & Carruthers et al. (2005) \\
\hline Trip generation & Number of trips & Vulnerable populations segments (elderly, children, & Schmöcker et al. (2005) \\
\hline Trip distance & Distance of travel & disabled people, part-time job, job seekers) & Morency et al. (2011) \\
\hline Trip duration & Commuting times & & McQuaid and Chen (2012) \\
\hline \multicolumn{4}{|l|}{ Accessibility } \\
\hline Index of public transport & Availability of public transport (PT) & Transport provision per capita & \\
\hline $\begin{array}{l}\text { Index of disparity } \\
\text { between needs and } \\
\text { provision }\end{array}$ & $\begin{array}{l}\text { The difference between transport need } \\
\text { and the availability of public transport } \\
\text { (TD - PT) }\end{array}$ & $\begin{array}{l}\text { The gap existing between the social transport need, } \\
\text { and the provision of public transport available }\end{array}$ & \\
\hline \multicolumn{4}{|l|}{ Environmental justice } \\
\hline NATA diesel PM & Diesel particulate matter level in air & Average $\mu \mathrm{g} / \mathrm{m}^{3}$ & EPA (2015) \\
\hline $\begin{array}{l}\text { Traffic proximity and } \\
\text { volume }\end{array}$ & $\begin{array}{l}\text { Count of vehicles at major roads within } \\
500 \mathrm{~m} \text {, divided by distance in metres } \\
\text { (not } \mathrm{km} \text { ) }\end{array}$ & Average annual daily traffic & \\
\hline
\end{tabular}

or transport poverty 


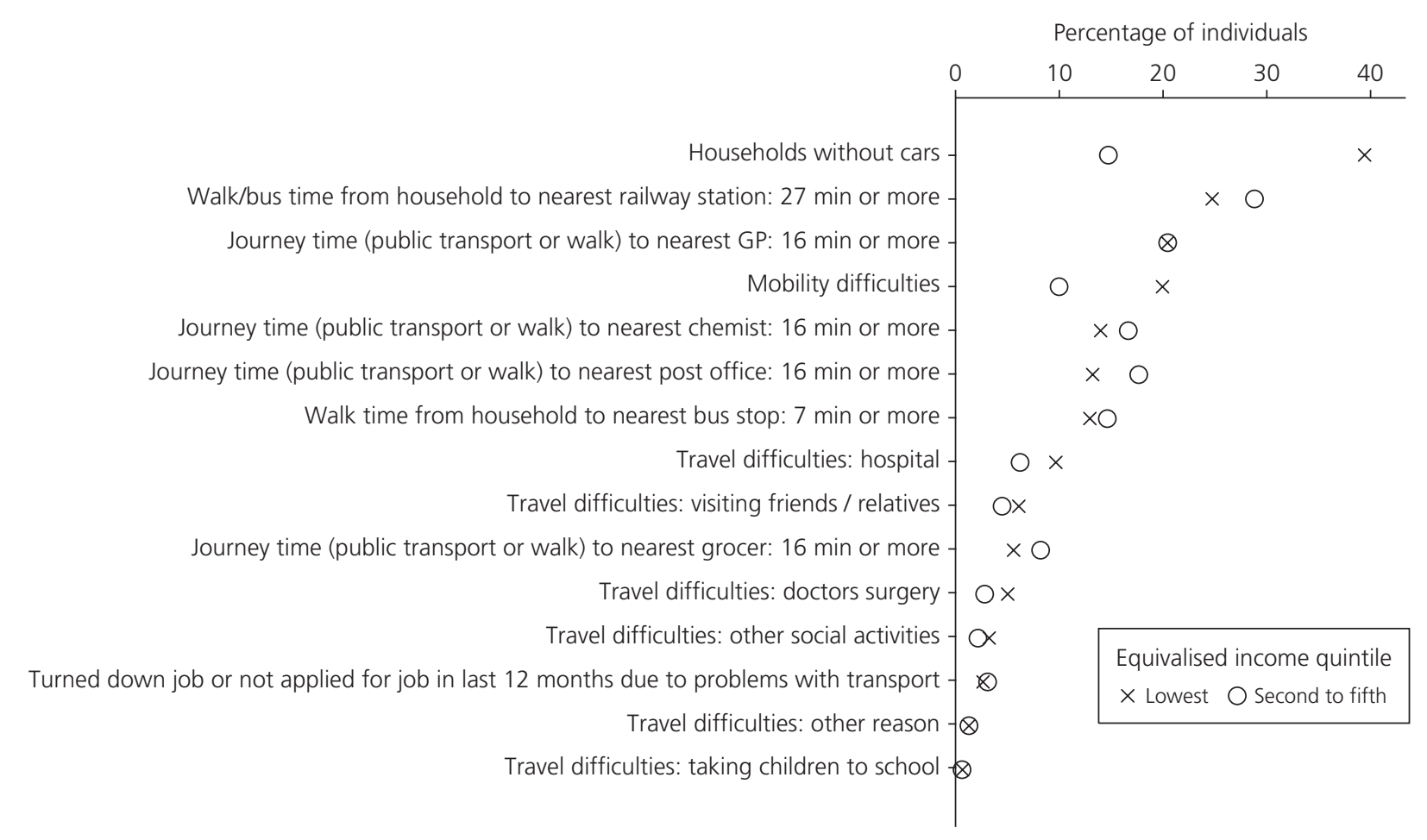

Figure 2. Indicators of transport poverty drawn from the National Travel Survey of Great Britain, 2012 (authors' own elaboration)

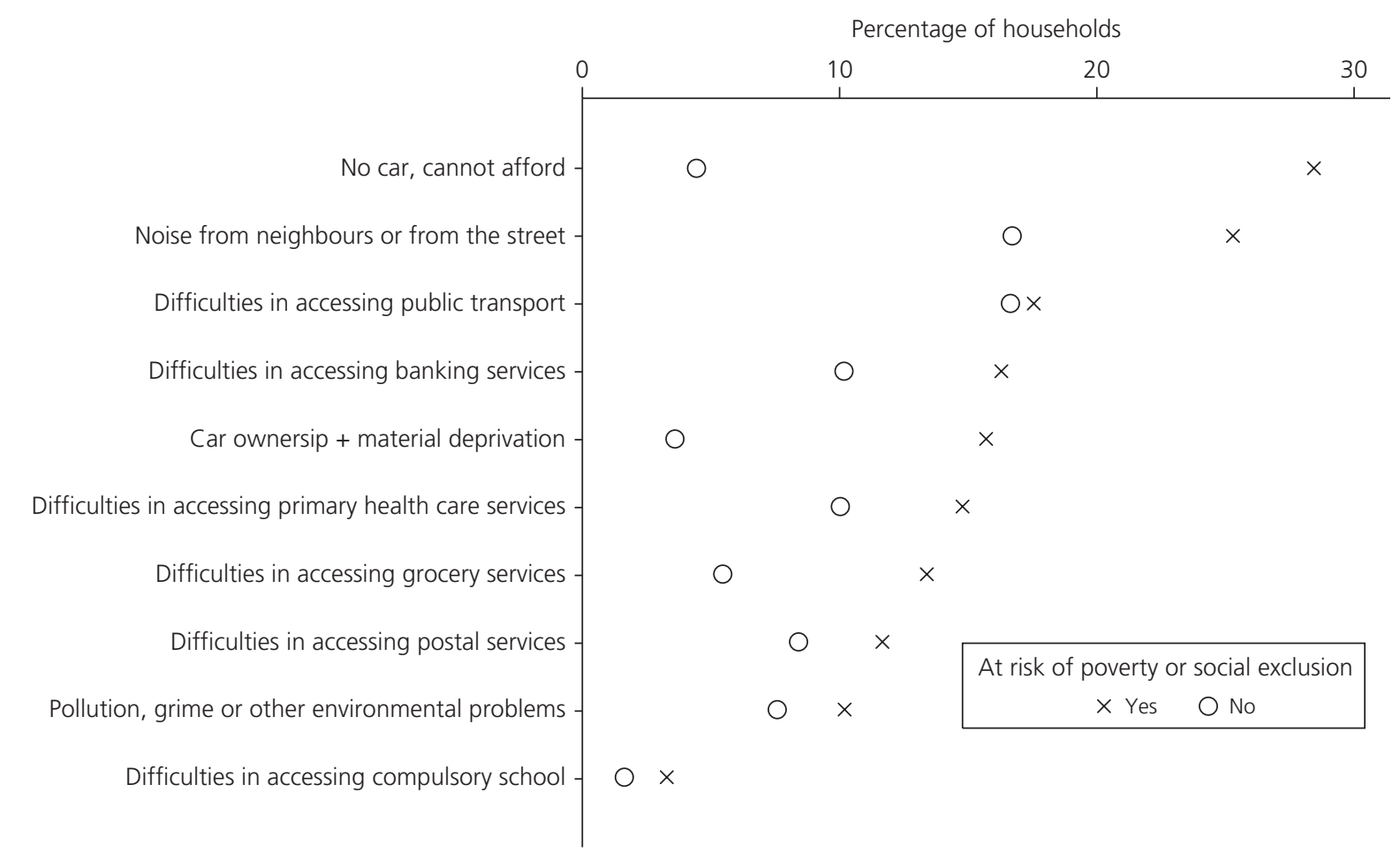

Figure 3. Indicators of transport poverty for the UK drawn from the EU statistics on income and living conditions (EU-SILC), 2012 (authors' own elaboration) 
to access transport' (SEU, 2003: p. 1). Halden et al. (2000) reviewed different accessibility measurement techniques, identifying that accessibility analysis always considers a location (origin or destination), the opportunities that people want to access and the 'separation' between people and those opportunities.

In Latin America, Jaramillo et al. (2012) adapted a methodology developed in Australia by Currie (2004) to undertake community-based measures of walking access to the bus rapid transit (BRT) system in Santiago de Cali, Colombia, based upon the area locations of each community, its demography and income characteristics. They concluded that the BRT did not improve the access of many of the isolated peripheral areas of the city, which are also the areas with higher levels of illiteracy, unemployment and higher numbers of households from low socio-economic strata (although at the time of the study only $9 \%$ of the system was operating). Other studies used a similar approach but have added activity-based measures of access to key destinations such as jobs, education, leisure and health (Delmelle and Casas, 2012). Bocarejo and Oviedo (2012) further build on this approach to include measures of travel time and costs in their analysis to reflect an understanding of affordability as a key dimension of access to services. Tiwari and Jain (2012) also measured accessibility to the Delhi BRT by calculating the number of destinations (by type) that are within reach of different types of road users, and the number and type of users for whom this metric has increased (compared to the pre-BRT situation).

In the context of the rural 'global south', engineers have played a central role in the development of assessment tools to measure transport poverty, such as the rural development index, which measures the access of the rural population to the road network (Roberts et al., 2006). These tools can play an important role in enhancing the geographical identification of transport poverty (as suggested by Howe (2001)). However, recent studies (Booth et al., 2000; Bryceson, 2009; Njenga and Davis, 2003; Porter, 2014) highlight the need for a more holistic planning approach in which the focus goes beyond infrastructure building to ensure well-being and accessibility. There is also a growing recognition of the importance of involving the local communities directly in the development of local transport projects at all stages of planning, design and implementation (Freeman, 2009).

\subsection{Measures of exposure to environmental externalities}

Most of the studies to develop measures of the disproportionate environmental exposures of low-income populations to various forms of transport externalities can be found within the US literature under the umbrella of environmental or transportation justice (Bailey et al. (2012) provide a useful summary of this). The US Environmental Protection Agency (EPA) has developed 12 environmental indexes based on existing demographics and environmental information (EPA, 2015). In the developing context, Venter et al. (2013) note that most evaluation studies of new transport projects fail to demonstrate explicitly the outcome for different types of household and populations sectors. They recommend detailed 'before and after' studies to understand better the impacts of large transport infrastructure projects on the poorest sectors of the population.

\subsection{Composite measures}

Numerous studies now point to the need for much more sophisticated, composite measures of transport and mobility that combine all these different aspects of its varied manifestations (e.g. Miller et al., 2013). These are necessary to understand and respond to the complex mobility needs of different individuals across the wide range of local contexts in which they live and carry out their daily routines (Ferreira and Batey, 2007). The authors recommend that measurement should not only take account of geographical contexts and the sociodemographic characteristics, daily activities and responsibilities and physical and cognitive capabilities of individuals, but also other factors relating to their environmental conditions, such as land uses, transport supply and environmental exposures. The complication here is that these measures generate a need for equally complex geo-coded travel survey data and complementary detailed land use and transport operating datasets of the kind that are rarely available in developing countries. The next section explores some of the datasets that are currently available to measure transport poverty in the UK context in order to identify the merits and limitations of the currently available datasets as a guide for future data collection.

\section{Data sources: merits and limitations}

While the previous sections have put forward a distinction between mobility poverty, accessibility poverty, transport affordability and exposure to environmental externalities, this section gives an overview of the types of data sources on transport poverty which are currently available in the UK. In doing so, transport poverty is referred to in a generic sense, as the fine distinctions between sub-concepts that have been put forward already are typically not reflected in survey questionnaire design. The the merits and limitations of available data sources are then highlighted, and suggestions are made for how they could be improved and how they could be adapted for use in a development context.

The UK government annually publishes accessibility statistics (DfT, 2014a) (i.e. estimates of travel times from where people live to key local services (e.g. employment, education, health, food retail and town centres) with reference to different transport modes (e.g. public transport/walking, cycle, car)). These are available at a high level of geographical detail and are used in local planning. However, they are based on modelled (potential rather than revealed) journey times, and their spatial aggregation makes it hard to assess the effect of individual and 
household characteristics. In order to do this, it is necessary to use social survey data.

Although the primary aim of the national travel survey (NTS) is still to collect data on personal travel patterns (in terms of, for example, frequency, distance, mode choice, etc.), it also collects information on a range of other factors affecting travel. Questions on the accessibility of key local services have been part of the questionnaire since 1998, and questions on travel and mobility difficulties and reasonably detailed information on income have been included since 2002. Figure 2 shows the values of these indicators for low-income (lowest quintile) and other households, based on the latest data available for 2012 (DfT, 2014b). The proportion of households affected by at least one of the issues listed in the figure is $76 \%$ for low-income households and $64 \%$ for others, demonstrating that problems of access potentially affect the majority of the British population.

As such, the NTS provides reasonably comprehensive information on travel patterns and the accessibility of key services, but it is not an ideal data source for investigating standards of living. Given the complex interplay between poverty and transport-related social exclusion, this is a limitation. Since 2005, the EU statistics on income and living conditions (EU-SILC) have annually provided detailed harmonised data for all EU member states on income and living conditions at the household level. The comprehensiveness of the information collected on income, employment and living standards allows the identification of households 'at risk of poverty or social exclusion' (Arope) according to the official indicator adopted by the EU (Eurostat, 2012).

This refers to households either at risk of poverty, severely materially deprived or with very low work intensity. (In this context an household is at risk of poverty when equivalised net income (after social transfers) is less than $60 \%$ of the national median; severe material deprivation is defined as not being able to afford at least four out of nine items considered to be necessities (which includes, among other things, a car); very low work intensity, with reference to working age household members, is defined by the ratio between the number of worked and 'workable' months in the 12 months preceding the interview.) Although EU-SILC do not usually include questions on the accessibility of key services, these were included in 2007 and 2012 as part of an ad-hoc module on housing conditions. Figure 3 shows the values of these and other transport poverty indicators for the Arope group and for the rest of the population in the UK in 2012. The proportion of households affected by at least one of the issues listed in the figure is $70 \%$ for the Arope group and $47 \%$ for other households, demonstrating that such problems disproportionately affect groups that are already disadvantaged.

From the perspective of developing countries, the survey instruments and questions illustrated above would require careful, context-sensitive adaptation. The figures illustrated in Figures 2 and 3 suggest that in Britain, disadvantaged groups do not on average experience lower levels of access to public transport. They do, however, report higher difficulties in accessing key services. This is explained by lower levels of car ownership; $39 \%$ of low-income individuals did not have access to a household car in 2012, and 28\% of Arope households reported that they could not afford one. This is in a context where car dependence is very high: in 2012, 44\% of Britons (up from just $22 \%$ in 1983) considered the car as 'a necessity that adults should not have to do without' (Mack et al., 2012). This is the result of built environment and social factors that make access with alternative modes difficult in many contexts (Lucas and Jones, 2009). This explains why, as illustrated in Figure 3, $16 \%$ of Arope households own a car despite being in material deprivation (i.e. not being able to afford three or more out of nine items considered to be necessities). The phenomenon, which is sometimes referred to as 'forced car ownership' (Currie et al., 2009), can result in considerable economic stress for households.

Also, Figure 3 shows that Arope households are more likely to experience noise and air pollution in the neighbourhoods where they live, and these are often caused by traffic. Therefore, at-risk groups in Britain are not only disadvantaged in terms of access, but are also more exposed to the environmental externalities of a largely car-dependent transport system.

An overview of available UK and European data sources highlights that, even in this developed world context where data collection on people's travel behaviours is regularly undertaken and widespread access is given to them for the purposes of academic research, transport poverty is still a relatively underdeveloped research area that falls between the fields of transport and social research. Travel survey data do not allow for the proper identification of socially excluded groups and, in Britain, the focus of accessibility questions on travel time and public transport/walking does not allow a full grasp of transport poverty issues. Also, national travel surveys have different designs, even within the EU, making international comparison virtually impossible (Akkermans et al., 2013).

On the other hand, living conditions datasets include interesting information on transport poverty, but only to the extent that this fits into other more established research agendas such as material deprivation and housing poverty. A problem with both types of surveys is that there is generally no geographically detailed information on residence and activity destinations of individuals. This means that these surveys cannot be adequately synthesised based on their geographical location and so it is impossible to undertake any detailed modelled analysis of their travel behaviours and behavioural outcomes in the context of the transport systems to which they have (or do not have) access. 


\section{Conclusions: recommendations and policy responses}

It can be concluded from this brief overview of the literature and data that transport poverty is an extremely under-explored and poorly articulated problem even within developed countries. It is therefore of little surprise that it has not been properly communicated to the transport engineers, policymakers and consultants who are working on the ground to improve the transport systems of developing cities and their rural hinterlands.

The experience of developed countries has shown that, just as cities cannot build their way out of congestion, similarly they cannot build their way out of transport poverty. Even in countries such as the UK, with an extensive road network and high levels of car ownership, some sectors of the population (and notably the poorest and most vulnerable) are affected by transport poverty. Most notably, problems of accessibility, affordability of transport costs and exposure to externalities are very present, even in developed countries. This suggests that the current focus of transport engineers in the 'global south' on extending strategic road provision (e.g. as enshrined by the rural access index) needs to be complemented by a more nuanced understanding of the different facets of transport poverty. This paper puts forward a conceptual framework that may help in this endeavour.

However, the transport reality in developing countries is full of contrasts, which makes it hard to compare between as well as within developing and developed countries. Some generalisable similarities are that low-income groups usually spend a high percentage of their income on transport but have the lowest quality transport systems available to them, whereas higherincome groups spend a much lower share of their earning on transport and have the highest quality transport systems available to them. This is reflected in poorer income groups travelling less, walking more and limiting their travel to mandatory trips such as working and studying. They are also most often disproportionately exposed to unsafe and unhealthy travelling environments, leading to greater incidences of traffic-related deaths and exposures.

One of the main barriers to a better policy understanding of the problem of transport poverty is the level and sophistication of the available data that are needed to research the problem in any meaningful and geographically specific way. Collection of such data is both time burdensome and costly if it is to be executed with the level of rigour, regularity and transparency that is necessary for detailed analysis. As such, it is a luxury that most developing countries cannot afford. When data collection is made a requirement by external international development agencies and project funders, the data are not generally made publicly available in their raw form for the purposes of independent academic analysis. This detailed analysis is extremely important for the development of appropriate policy solutions, as well as to avoid the expense of poorly targeted policies for transport poverty alleviation.

For example, currently many countries around the world offer blanket concessionary fares to certain targeted population groups, such as older and disabled people and without assessing their actual transport needs. This comes at an extremely high cost to the public purse and may not even be targeting the people who are most in need of assistance (Mackett, 2014). Furthermore, many of the people in receipt of such subsidies may not be able to use the public transport services either because they live in unserved areas or because of physical or cognitive barriers to their use. On the other hand, the specialist services that have been adapted for use by people with disabilities may not be free to them at the point of delivery and so unaffordable to use. Moreover, there are many social groups that experience transport poverty who do not currently receive such policy considerations at all, such as young people who are not in education and so must pay the full fare to travel on public transport even if they are in lowincome households or living independently from their families on a low wage.

Some countries in the 'global north', such as the USA, UK and France, have experimented with targeted small-scale transport interventions to assist people in transport poverty (see e.g. Lucas et al., 2006). Interventions have included the provision of private motor vehicles; other schemes have offered free bus passes or community transport services or motorscooter or bicycle loans. Although these policies may effectively target the transport poverty of specific individuals, they do not provide a cost-effective way to address the widespread issues of transport poverty identified in this paper. It is also unlikely that such policies could be introduced in any comprehensive way within the development context, where levels of excessive motorisation are already negatively affecting people's quality of life in most large cities. Neither do they do anything to reverse the disproportionate negative impacts of the traffic system on countless transport-poor communities worldwide.

\section{Acknowledgements}

The NTS 2002-2012 data sets of the UK Department for Transport were kindly provided by the Economic and Social Data Service (ESDS) through the UK Data Archive at the University of Essex, Colchester. The original data creators, depositors, copyright holders and the UK Data Archive bear no responsibility for their further analysis or interpretation. The EU-SILC 2012 data set was kindly provided by Eurostat. The responsibility for all conclusions drawn from the data lies entirely with the authors.

\section{REFERENCES}

Abley S (2010) Measuring Accessibility and Providing Transport

Choice. Australian Institute of Traffic Planning and

Management (AITPM), Brisbane, Australia. 
Ahrend C, Schwedes O, Daubitz S, Böhme U and Herget M (2014) Kleiner Begriffskanon der Mobilitätsforschung. Fachgebiet Integrierte Verkehrsplanung, Technische Universität Berlin, Berlin, Germany, discussion paper (in German).

Akkermans L, Maerivoet S, Ahern A et al. (2013) Harmonisation of National Travel Statistics in Europe. Publications Office of the European Union, Luxembourg City, Luxembourg.

Bailey K, Grossardt T and Ripy J (2012) Toward environmental justice in transportation decision making with structured public involvement. Transportation Research Record 2320: $102-110$.

Barter PA (1999) Transport and urban poverty in Asia: a brief introduction to the key issues. Regional Development Dialogue 20(1): 143-163.

Bocarejo SJP and Oviedo HDR (2012) Transport accessibility and social inequities: a tool for identification of mobility needs and evaluation of transport investments. Journal of Transport Geography 24: 142-154.

Booth D, Hanmer L and Lovell E (2000) Poverty and Tansport. A Report Prepared for the World Bank in Collaboration with DFID. Overseas Development Institute, London, UK.

Bouzarovski S and Petrova S (2015) A global perspective on domestic energy deprivation: overcoming the energy poverty-fuel poverty binary. Energy Research and Social Science 10: 31-40.

Bryceson D (2009) Roadmapping development and poverty alleviation-transport and the millennium development goals in Africa. In Africa, Transport and the Millennium Development Goals: Achieving an Internationally Set Agenda (Grieco G, Ndulo M, Bryceson D, Porter G and McCray T (eds)), pp. 1-24, Cambridge Scholar Publishing, Newcastle upon Tyne, UK.

Carruthers R, Dick M and Saurkar A (2005) Affordability of Public Transport in Developing Countries. The World Bank Group, Washington, DC, USA, Transport Papers, vol. TP-3, pp 1-27.

CBT (Campaign for Better Transport) (2012) Transport and Poverty: A Literature Review. CBT, London, UK.

Cebollada Á (2006) Aproximación a los procesos de exclusión social a partir de la relación entre el territorio y la movilidad cotidiana. Documents d'Anàlisi Geogràfica 48 : 105-121 (in Spanish).

Currie G (2004) Gap analysis of public transport needs. measuring spatial distribution of public transport needs and identifying gaps in the quality of public transport provision. Transportation Research Record 1895: 137-146.

Currie G and Delbosc A (2013) Exploring trends in forced car ownership in Melbourne. Proceedings of the 36th Australasian Transport Research Forum (ATRF), Brisbane, Queensland, Australia. Department of Infrastructure and Regional Development, Canberra, Australia, pp. 1-9.

Currie G, Richardson T, Smyth P et al. (2009) Investigating links between transport disadvantage, social exclusion and well-being in Melbourne-preliminary results. Transport Policy 16(3): 97-105.
Delmelle EC and Casas I (2012) Evaluating the spatial equity of bus rapid transit-based accessibility patterns in a developing country: the case of Cali, Colombia. Transport Policy 20: 36-46.

Denmark D (1998) The outsiders: planning and transport disadvantage. Journal of Planning Education and Research 17(3): 231-245.

DfT (Department for Transport) (2014a) Accessibility Statistics 2013. Department for Transport, London, UK. DfT (2014b) National Travel Survey, 2002-2012, 8th edn. UK Data Archive [distributor], Colchester, Essex, UK.

DfT (2006) Accessibility Planning: Full Guidance. Department for Transport, London, UK.

Dodson J and Sipe N (2007) Oil vulnerability in the Australian city: assessing socioeconomic risks from higher urban fuel prices. Urban Studies 44(1): 37-62.

EPA (US Environmental Protection Agency) (2015) EJSCREEN: Environmental Justice Screening and Mapping Tool. EPA, Washington, DC, USA. See http://www.epa.gov/ejscreen (accessed 15/11/2015).

Eurostat (2012) Measuring Material Deprivation in the EU. Indicators for the Whole Population and Child-Specific Indicators, 2012 edn. Publications Office of the European Union, Luxembourg City, Luxembourg.

Ferreira A and Batey P (2007) Re-thinking accessibility planning. The Town Planning Review 78(4): 429-458.

Freeman PN (2009) Ten years of World Bank action in transport: evaluation. Journal of Infrastructure Systems 15(4): 298-304.

Gachassin M, Najman B and Raballand G (2010) The Impact of Roads on Poverty Reduction: A Case Study of Cameroon. World Bank, Washington, DC, USA, Policy Research Working Paper 5209, pp. 1-37.

Gleeson B and Randolph B (2002) Social disadvantage and planning in the Sydney context. Urban Policy and Research 20(1): 101-107.

Gwilliam KM (2002) Cities on the Move: $a$ World Bank Urban Transport Strategy Review. World Bank Publications, Washington, DC, USA.

Halden D, McGuigan D, Nisbet A and McKinnon A (2000) Accessibility: Review of Measuring Techniques and their Application. Scottish Executive Central Research Unit, Edinburgh, UK.

Harris B (2001) Accessibility: concepts and applications. Journal of Transportation and Statistics 4(2/3): 15-30.

Harvey D (2003) The right to the city. International Journal of Urban and Regional Research 27(4): 939-994.

Hettige H (2006) When Do Rural Roads Benefit the Poor and How? An In-Depth Analysis Based on Case Studies. Asian Development Bank (ADB), Manila, Philippines.

Hine J (2009) Transport and Social Exclusion. Elsevier, Newtownabbey, UK.

Howe JDGF (2001) Poverty and urban transport in East Africa. Proceedings of the Institution of Civil Engineers Municipal Engineer 145(4): 267-271. 
Isalou AA, Litman T and Shahmoradi B (2014) Testing the housing and transportation affordability index in a developing world context: a sustainability comparison of central and suburban districts in Qom, Iran. Transport Policy 33: 33-39.

Jaramillo C, Lizarraga C and Grindlay AL (2012) Spatial disparity in transport social needs and public transport provision in Santiago de Cali (Colombia). Journal of Transport Geography 24: 340-357.

Khandker SR and Koolwal GB (2011) Estimating the Long-term Impacts of Rural Roads: A Dynamic Panel Approach. World Bank, Washington, DC, USA, Policy Research Working Paper 5867.

Litman T (2015) Transportation Affordability. Evaluation and Improvements Strategies. Victoria Transport Policy Institute, Victoria, Canada.

Lucas K (ed.) (2004) Running on Empty: Transport, Social Exclusion and Environmental Justice. The Policy Press, Bristol, UK.

Lucas K (2012) Transport and social exclusion: where are we now? Transport Policy 20: 105-113.

Lucas K and Jones P (2009) The Car in British Society. RAC Foundation, London, UK.

Lucas K and Markovich J (2011) International perspectives. In New Perspectives and Methods in Transport and Social Exclusion Research (Currie G (ed.)). Emerald, Bingley, UK, pp. 223-239.

Lucas K, Tyler S, Cervero R and Orfeuil J (2006) Moving from Welfare to Work: The Role of Transport. FIA Foundation, London, UK.

Mack J, Lansley S, Nandy S and Pantazatis C (2012) Attitudes to Necessities in the PSE 2012 Survey: Are Minimum Standards Becoming Less Generous? PSE UK, London, UK, working paper, Analysis Series no. 4, pp. 1-23.

Mackett R (2014) Has the policy of concessionary bus travel for older people in Britain been successful? Case Studies for Transport Policy 2(2): 81-88.

Maoh H and Tang Z (2012) Determinants of normal and extreme commute distance in a sprawled midsize Canadian city: evidence from Windsor, Canada. Journal of Transport Geography 25: 50-57.

Martens K (2013) Role of the bicycle in the limitation of transport poverty in the Netherlands. Transportation Research Record 2387: 20-25.

Martens K and Bastiaanssen J (2014) An index to measure accessibility poverty risk. Proceedings of Colloquium Vervoersplanologisch Speurwerk, Eindhoven, the Netherlands

McQuaid R and Chen T (2012) Commuting times - the role of gender, children and part-time work. Research in Transportation Economics 34(1): 66-73.

Miller HJ, Witlox F and Tribby CP (2013) Developing context-sensitive livability indicators for transportation planning: a measurement framework. Journal of Transport Geography 26: 51-64.
Moore J, Lucas K and Bates J (2013) Social Disadvantage and Transport in the UK: A Trip-based Approach. School of Geography and the Environment, University of Oxford, Oxford, UK, TSU Working Paper Series, Ref. 1063.

Morency C, Paez A, Roorda M, Mercado R and Farber S (2011) Distance travelled in three Canadian cities: spatial analysis from the perspective of vulnerable population segments. Journal of Transport Geography 19(1): 39-50.

Mu R and van de Walle D (2011) Rural roads and local market development in Vietnam. Journal of Development Studies 47(5): 709-734.

Njenga P and Davis A (2003) Drawing the road map to rural poverty reduction. Transport Reviews 23(2): 217-241.

Olvera LD, Plat D and Pochet P (2008) Caminar y nada más. Movilidad diaria y pobreza en las ciudades subsaharianas. Scripta Nova XII(261). See http://www.ub.edu/geocrit/sn/ sn-261.htm (accessed 29/02/2016; in Spanish).

Pereira RH and Schwanen T (2013) Commute Time in Brazil (1992-2009): Differences between Metropolitan Areas, by Income Levels and Gender. IPEA (Institute for Applied Economic Research), Brasilia, Brazil.

Pinto de Freitas IM (2005) Inclusão social pela mobilidade: o caso da região Metropolitana de Salvador. Proceedings of the XIII Congreso Latinoamericana de Transporte Público y Urbano, Actas del XIII CLATPU, Lima, Peru, pp. 3-37 (in Spanish).

Porter G (2014) Transport services and their impact on poverty and growth in rural sub-saharan Africa: a review of recent research and future research needs. Transport Reviews 34(1): 25-45.

Preston J and Rajé F (2007) Accessibility, mobility and transport-related social exclusion. Journal of Transport Geography 15(3): 151-160.

RAC (Royal Automobile Club) Foundation (2012) 21 Million UK Households in Transport Poverty. RAC Foundation, London, UK. See http://www.racfoundation.org/mediacentre/transport-poverty (accessed 22/09/2015).

Roberts P, KC S and Rastogi C (2006) Rural Access Index: A Key Development Indicator. The World Bank Group, Washington, DC, USA, Transport Papers, vol. TP-10.

Robinson R and Thagesen B (2004) Road Engineering for Development. Spon Press, London, UK and New York, NY, USA.

Rodrigue JP, Comtois C and Slack B (2006) The Geography of Transport Systems. Routledge, New York, NY, USA.

Roorda M, Paez A, Morency C, Mercado R and Farber S (2010) Trip generation of vulnerable populations in three Canadian cities: a spatial ordered probit approach Transportation 37(3): 525-548.

Scheiner J (2008) Accessibility, spatial context and location preferences: is there evidence for accessibility poverty? In How to Define and Measure Access and Need Satisfaction (Becker U, Böhmer J and Gerike R (eds)). Transport Series of Dresden Institute for Transportation and Environment (DIVU), Dresden, Germany, pp. 193-225. 
Schmöcker J, Quddus M, Noland R et al. (2005) Estimating trip generation of the elderly and disabled people: an analysis of London data. Transportation Research Record 1924: 9-18.

Serebrisky T, Gómez-Lobo A, Estupiñán N and Muñoz-Raskin R (2009) Affordability and subsidies in public urban transport: what do we mean, what can be done? Transport Reviews: A Transnational Transdisciplinary Journal 29(6): 715-739.

SEU (Social Exclusion Unit) (2003) Making the Connections: Final Report on Transport and Social Exclusion. Office of the Deputy Prime Minister, London, UK.

Soja EW (2010) Seeking Spatial Justice. University of Minnesota Press, Minneapolis, MN, USA.

Starkey P and Hine J (2014) Poverty and Sustainable Transport: How Transport Affects Poor People with Policy Implications for Poverty Reduction. A Literature Review. ODI, UN-Habitat, DFID, UKaid, SLoCaT, London, UK.

Sustrans (2012) Measuring and Mapping Transport Poverty. Sustrans, Bristol, UK. See http://www.sustrans.org.uk/ measuring-mapping-transport-poverty (accessed 22/09/ 2015).
Titheridge $\mathrm{H}$, Christie N, Mackett R, Oviedo Hernandez D and Ye R (2014) Transport and Poverty. A Review of the Evidence. UCL, London, UK.

Tiwari G and Jain D (2012) Accessibility and safety indicators for all road users: case study Delhi BRT. Journal of Transport Geography 22: 87-95.

UN-Habitat (2013) Planning and Design for Sustainable Urban Transport. Global Report on Human Settlements 2013. Earthscan, Abingdon, UK.

Van den Berg P, Arentze T and Timmermans H (2011) Estimating travel demand of senior citizens in the Netherlands. Journal of Transport Geography 19(2): 323-331.

Velaga NR, Beecroft M and Nelson JD (2012) Transport poverty meets the digital divide: accessibility and connectivity in rural communities. Journal of Transport Geography (21): 102-112.

Venter C, Hidalgo D and Pineda A (2013) Assessing the equity impacts of bus rapid transit: emerging frameworks and evidence. Proceedings of the 13th World Conference on Transportation Research, Rio de Janeiro, Brazil, pp. 1-18. 